\title{
TOPICS
}

\section{猪苗代第三・第四発電所と 近代化の諸相}

(所在地：福島県猪苗代市)

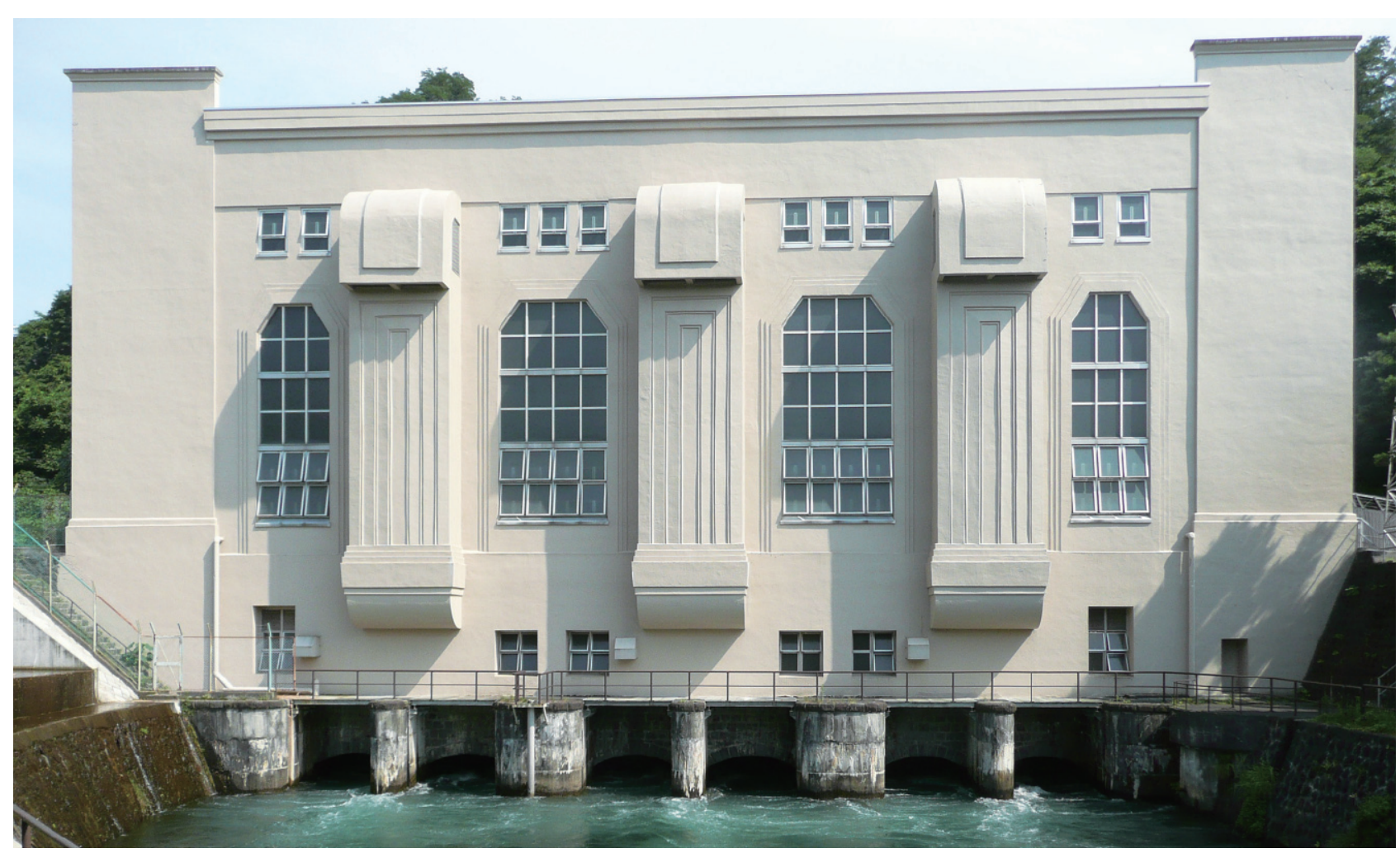

写真-1 猪苗代第三発電所（写真提供 : 東京電力(株猪苗代電力所）

福島県猪苗代市に現存する東京電力「猪苗代第三・第四発電所」(写真-1, 写真-2) は, 大正 15 年 (1926 年)に完成し た鉄筋コンクリート造の建築で，オーダーを模した個性的なピラスターを今に伝えている。

両発電所を創建した東京電燈株式会社は明治 16 年 (1883 年)に創立された。族生した電力会社を合併・統合しながら成 長していった日本最初の電力会社である。猪苗代水力電気株式会社はその被合併会社の一つ（大正 12 年合併）で，仙石貢 · 白石直治といった鉄道官僚や，渋沢栄一・近藤廉平ら政財界の雄による発起のもと，明治 44 年 (1911 年)に創立された。 中央のための電源を中央の資本で開発するべく実現した，日本の近代化を象徵する一大企業であった。

明治中期以降, 琵琶湖疎水を活用した蹴上発電所（明治 24 年送電開始）を嗃矢に，国内では大小さまざまな一般供給用 の水力発電所が計画された。時代は都市の明かりが石油灯・ガス灯から炭素線電球・タングステン電球へ，工業の動源が 汽力から電力へと転換した画期。富国強兵という国家目標, 日露戦争を起因とした電力需要の増加も背景に, 電源開発を めぐる利権獲得競争が加速していった。その水利の有望さから，猪苗代湖周辺は競争の一最前線となったのである。

猪苗代水力電気会社の計画にあたり，莫大なコストとデザイン・リソースが注がれた。初代社長を務めた仙石貢は，「設 計・工事とも当代最優秀のものとせよ。これがためには資金を惜しむべからず」と命じたのである。この気焔はやがて, 猪苗代から東京田端給電所までを繋ぐ約 225 キロもの長距離高圧送電線と，辰野金吾（1854-1919）の監修による「猪苗代 第一発電所」（大正 3 年創建・主構造鉄骨棟瓦造・翌年送電開始）とを実現させるに至った。中央のための電力源と送電 ンフラが, 当時最先端のデザインにより東北の地に誕生したのである。なお, 現存する「猪苗代第二発電所」(大正 7 年創 建・写真-3）は,「猪苗代第一発電所」の設計を踏襲することで実現したものである。

「猪苗代第三・第四発電所」は鉄筋コンクリート造の建築として, 辰野が没した大正 8 年 (1919 年) の翌年から起工され る。鉄骨棟瓦造が採用された第一・第二発電所と比べ，「当代最優秀」の建築の有り様に大きな変化がみられ興味深い。明 治期末は, 日本初の総鉄筋コンクリート造となる「三井物産横浜支店」（1911 年, 設計遠藤於菟・構造計算佐野利器）など, 日本で建築の主構造にコンクリート造が採用され始めた時代。「東京駅丸の内本屋」（1914 年）の設計では，辰野はコンク リートへの不信感から，スラブにこそ炭殼コンクリートを用いたものの，主構造には鉄骨煉瓦造を選んだ。時代は建築構 造・材料への理解が大きく転換した過渡期であった。

猪苗代水力発電所には, 中央のための電源開発をめぐる社会背景にとどまらず, 建築の構造・材料とその理解の系譜な ど，日本の近代化をめぐる様々な痕跡が見え隠れしているのである。 


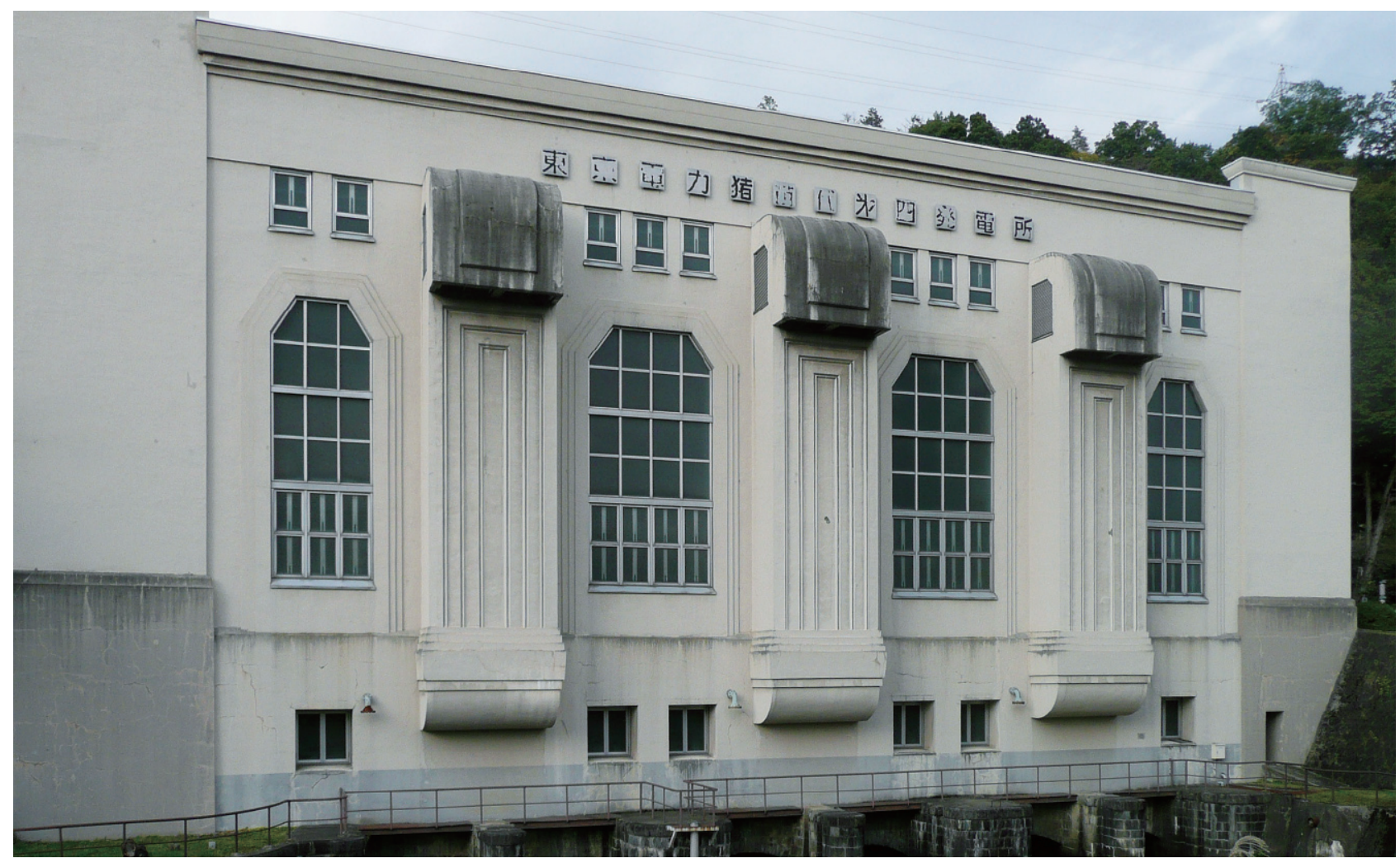

写真-2 猪苗代第四発電所（写真提供 : 東京電力(株猪苗代電力所）

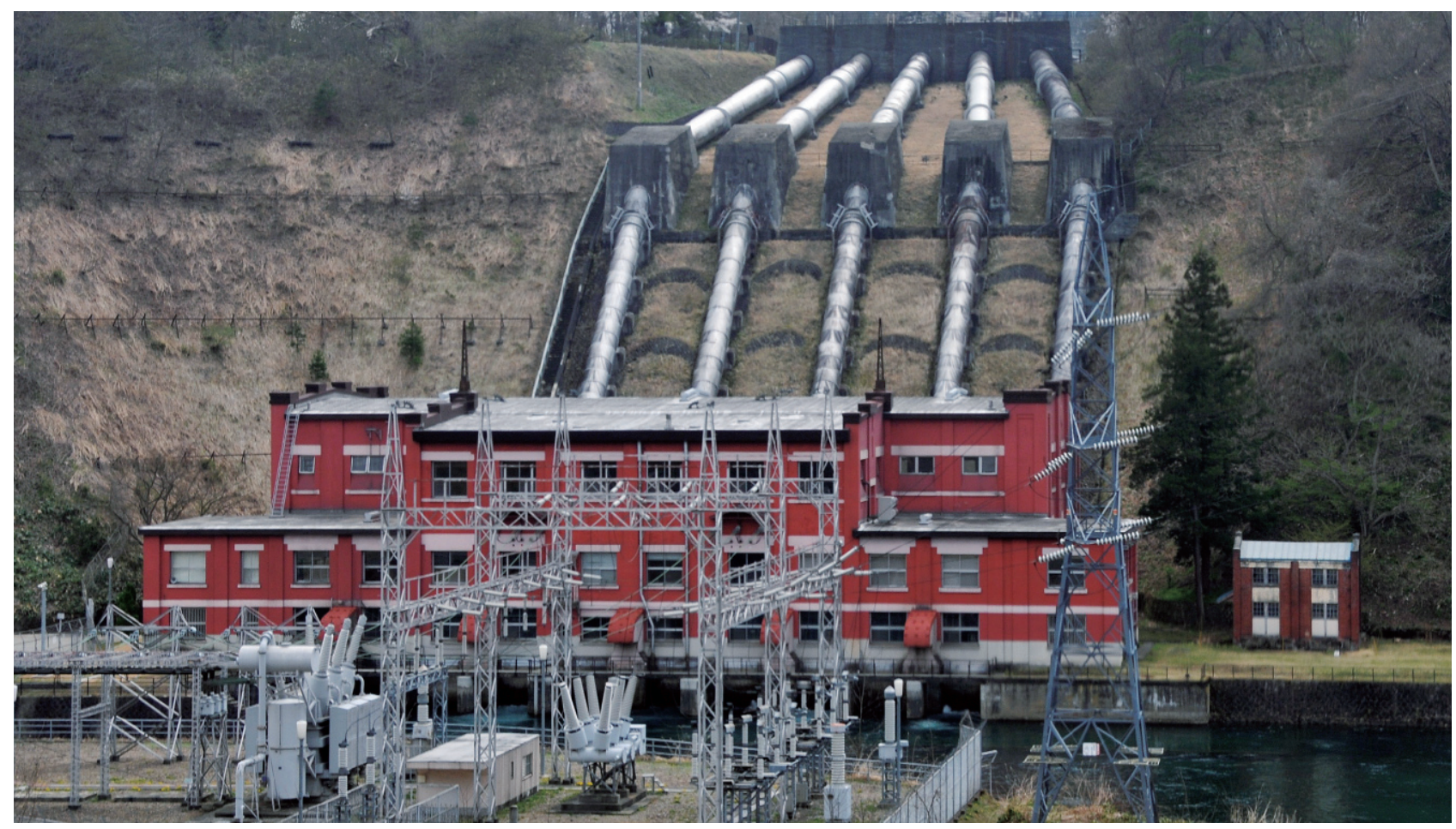

写真-3 猪苗代第二発電所（写真提供：東京電力(侏猪苗代電力所）

参考文献

福島県：福島県史 第 4 巻 通史編 4 近代 1,1971

会津若松市：会津若松史 第 7 卷 大正・昭和の会津, 1967

宮城県教育委員会：宮城県の近代化遺産 宮城県近代化遺产総合調查報告書, 2002

藤森照信：日本の近代建築（下) 一大正・昭和篇一, 岩波書店, 1993

編集・文責 : 野村俊一（東北大学） 